World Lumen Congress 2021 | May 26-30, 2021 |

Iasi, Romania

\title{
Determining Factors for Achieving Success in Entrepreneurship
}

\author{
Monica COJOCARU, Valentin RADU, Ayten Güler \\ DERMENGI
}

https://doi.org/10.18662/wlc2021/14

How to cite: Cojocaru, M., Radu, V., \& Dermengi, A. G. (2021). Determining Factors for Achieving Success in Entrepreneurship. In A. Sandu (vol. ed.), Lumen Proceedings: Vol. 17 World Lumen Congress 2021 (pp. 131-140). Iasi, Romania: LUMEN Publishing House. https://doi.org/10.18662/wlc2021/14 


\title{
Determining Factors for Achieving Success in Entrepreneurship
}

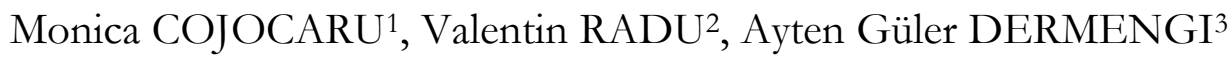

\begin{abstract}
This paper represents the quintessence of our own research on the critical success factors identified by analysing the lives and deeds of 10 world leaders from an entrepreneurial perspective. In the research we looked for the answers to a series of questions such as: What defines these action people, who have calculated and taken risks to achieve the proposed objectives? What motivated these personalities to conquer minds, hearts, and territories? Where did they get the courage, they needed to act according to their dream? What were their strengths? What defines and differentiates a successful manager? Where is the boundary between the managerial style beneficial to the organization and the sinusoidal approach of the managerial path? The paper was made by substantiating these answers and developing a list of determining factors in achieving the success of an entrepreneur. The results obtained constitute a decalogue for entrepreneurs to achieve added value for the businesses they implement.
\end{abstract}

Keywords: Entrepreneur, success, motivation, factors, manager.

\section{Introduction}

The paper aims to identify the characteristics that characterize successful people, including prominent figures in business, such as T.A. Edison, H. Ford or J.D. Rockefeller. We wonder what additional qualities they had or if they had resources inaccessible to others, understood truths difficult to access or acted differently from the majority.

Starting from this intense interest, first part of the paper is reserved for the research result obtained by people interested in knowing the deep, little visible forces that trigger and support success in general and entrepreneurial success, specifically.

Another part of the work is the result of the authors' own research who set

1 PhD Candidate, Valahia University of Targoviste, Targoviste, Romania. E-mail: monica.cojocaru@,comoconsulting.ro

2 Associate Professor, Valahia University of Targoviste, Targoviste, Romania. E-mail: valentin.radu@,valahia.ro

3 PhD Candidate, Valahia University of Targoviste, Targoviste, Romania. E-mail: aytengerea@gmail.com 
out to study ten prominent figures in history whose deeds still influence our lives (Napoleon Bonaparte, Timur Lenk, Winston Churchill, Adolf Hitler, Queen Elizabeth I, Catherine the Great, Potemkin, Ecaterina Teodoroiu, Mahatma Ghandi and Dalai Lama) and identify from their own perspective what are the critical success factors.

The paper also inserts the results of studies conducted by the business environment, interested in identifying the factors that trigger and support long-term success. Finally, the last part of the paper is dedicated to the identification of common points in the analysed studies.

The objectives of the article are: 1 . identification of attributes with a positive impact during the leadership activity and 2. finding the inner human forces that obstruct the sustainability of success.

\section{Literature Review}

The current European context encourages entrepreneurial initiatives by ensuring a favourable climate and, where appropriate, sources of funding from the Structural Funds. Inevitably, the question arises whether potential entrepreneurs are prepared to put entrepreneurial ideas into practice and how we can characterize a successful entrepreneur. Economic theories attribute to the entrepreneur a wide variety of functions. A number of functional aspects appear in many different theories and identify the factors of success or failure in entrepreneurship. In order to fix the determinants of success in entrepreneurship, we analyse a series of perceptions on the notion of success or entrepreneurial failure, which will also allow the fixation of the principles of action that have characterized a series of leaders.

In order to form a more exact and correct perception of the notion of entrepreneurial success we have synthesized some theories from the specialized literature.

Makhbul and Hasun (2011) conduct an investigation of previous studies to identify entrepreneurial factors that may contribute to success in entrepreneurship. In addition to the desire for success and decision-making skill, the authors highlight other outstanding qualities such as self-confidence, independence and innovativeness as well as good communication. Other characteristics of successful entrepreneurs include high self-efficacy, opportunity recognition, perseverance and social skills Markman \& Baron (2003).

For Santos (2012) "Success means being free, both financially and emotionally". It means to act in such a way that things happen in your favor, not at random/it means to create your opportunities.

Hill (2014) considers that success in life "is largely a matter of adapting to the environment in such a way that there is harmony between the individual and the environment". However, in order to find out the common area of success, an area to which the majority of those who ardently wish success are subordinated, I appealed to the conclusions drawn by one of the most prominent figures in American literature, whose works were among the best-selling of all time. The study 
also highlighted seventeen principles of the Law of Success (Table 1) designed to ensure increased productivity, from a financial point of view, in solving economic problems, regardless of the field of activity.

Table 1. Principles of possible success in entrepreneurship

\begin{tabular}{|c|c|}
\hline $\begin{array}{l}\text { Principles of } \\
\text { Success }\end{array}$ & Forms of manifestation \\
\hline $\begin{array}{l}\text { Supreme Mind } \\
\text { (egregor) }\end{array}$ & $\begin{array}{l}\text { Collective mind obtained by connecting individual } \\
\text { minds that coordinate their skills, knowledge, } \\
\text { experience and energy in a spirit of perfect harmony to } \\
\text { achieve a common, clearly defined goal based on a well- } \\
\text { defined plan to achieve the goal, followed systematically } \\
\text { and continuously, day by day through an organized, } \\
\text { directed and harmoniously coordinated effort operating } \\
\text { in the spirit of harmonious cooperation. }\end{array}$ \\
\hline
\end{tabular}

The importance of a clear purpose

Confidence

The habit of saving

Initiative and leadership

Imagination

Enthusiasm

Self-control

The habit of doing more than you is paid to do
$90 \%$ of what makes up success is knowing exactly what you want.

It is the result of the analysis, identification and elimination of the type of fear (criticism, illness, poverty, poverty, loss of someone's love, death) that lies between you and self-confidence.

Systematic saving gives you confidence and autonomy that you cannot gain otherwise.

"People are paid not only for what they know, but especially for what they do with what they know or help others do" so take the initiative and start putting the plan into action!

It gets stronger when you create new combinations of ideas.

It is a mental vibration with a higher frequency, having as a starting point the well-defined motivation or desire, which gives great power to the one who has it, is contagious and influences everyone who comes in contact with the owner.

Success in life is very much a matter of harmonious negotiation with other people, and this requires abundant self-control.

By performing a workload in addition to the one for which you are paid, you draw attention to yourself in a positive way and benefit from the law of increased return (in one way or another, you will be rewarded for 


\section{A pleasant personality}

Precise thinking

Concentration

Cooperation

Know how to take advantage of a failure

Tolerance

The Golden Rule for obtaining cooperation

The habit of maintaining health much more than what you actually do).

It is usually characteristic of people who speak gently, kindly, in a modest tone of voice, who use words that do not offend and wear clothes with a suitable style and matching colours.

There are people who are unselfish, eager to help others, friendly to everyone regardless of status, political choices or religion.

Ask, before issuing opinions on a particular subject or making any decision; classifying the facts as important (to achieve the purpose or daily) or irrelevant.

Involves: find out what you want; to assume a main purpose, clear to focus all your attention (thought, effort, energy), one at a time, on one thing at the service of the main goal you have.

You will make others cooperate with you if you cooperate with them first! It brings together energies, in the spirit of the harmony of purpose, so that the result is unitary and works without friction.

Failure is a disguised blessing, provided it provides us with a useful lesson that, in its absence, we would not have had or could not have learned.

However, the successful people are those who had a firm attitude (they looked at the defeat in front, remaining absolutely steadfast) on the way to achieving the goal, well defined.

It is the opposite of ignorance (of lack of knowledge) and occurs in people who know that no one has enough knowledge to be justified in judging others.

"Anything attracts something like it" (success is attracted to success, and failure to failure; if you praise, you will be praised; if you do someone a favour in business and you will be favoured)

Every thought you have, every deed you do gathers other thoughts and deeds of the same nature that will come back to you at the right time!

Health largely depends on: -adequate food and fresh air, -regular excretion, -adequate exercise program, -fair judgment.

Source: Author's interpretation of Hill (2014)

Thus, we find that the idea of starting a business is of course the reasons and conditions, macro and microeconomic factors that can influence to some extent the decision to launch your own business. The same idea can have different consequences depending on the development of the economy in which it will be implemented (Beattie, 2016). The entrepreneurial perspective is influenced by a number of external factors such as location, social context, economic crises, target 
clients, etc., but the paper highlights the possible internal qualities for a successful entrepreneur.

To substantiate these theories, ten remarkable figures of history were selected and analysed, whose deeds still inspire and influence people. Although the historical course presents a vast list of important personalities, our study focused on those people whose mental strength, tripled by a firm attitude and exceptional leadership, inspired minds and souls and changed destinies. People whose greatness inspires the business environment, regardless of the field of activity are:

- Napoléon Bonaparte - political and military leader of France, whose actions have strongly influenced European policy since the early nineteenth century (Montefiore, 2016a; Fremont-Barnes, 2014);

- Timur Lenk - mongolian conqueror, founder of an empire and a dynasty, "genius of propaganda and communication" considered to be the most experienced military leader in history (Blin, 2013; Simu, 2008);

- Winston Churchill - respected as one of the greatest war leaders of the century (Johnson, 2016; Shelden, 2014);

- Adolf Hitler - whose "aggressive expansionist policy is considered the main cause of the outbreak of World War II, resulting in colossal human losses" (Buckley, 2019; Orbach, 2020).

- Queen Elisabeth I - perhaps England's most representative leader, "a brave and fearless leader" who knew how to "be with her people" and encourage them in times of crisis (Avram, 2014; Eding, 2016);

- Catherine the Great - a talented politician, a statesman with the ability to think long-term, a character who radiated invincibility and burning ambition to lead the Russian Empire (Montefiore, 2016a; Avram, 2014);

- Grigori Potemkin- is one of Russia's most remarkable statesmen, the man for whom nature had used "the material necessary for a hundred men," who never walked the beaten path and yet reached his destination (Avram, 2014; Montefiore, 2016b);

- Ecaterina Teodoroiu - the Romanian national hero whose love of country, fighting spirit, patriotism and sacrificial power were at the height of the bravest local defenders (Avram, 2014);

- Mahatma Ghandi - lawyer, social activist, Indian politician and writer, initiator of nonviolent revolt movements aimed at gaining India's independence from the British Empire (Gandhi, 2019; Rolland, 2019);

- Dalai Lama - winner of the Nobel Peace Prize in 1989, a tireless promoter of messages of non-violence, compassion and love, whose deeds change characters (Lama, 2018, 2019).

Therefore, these people who have impacted the chain for generations, have been endowed but have also developed with perseverance and discipline, exceptional qualities that have ensured them a meteoric growth throughout history. 


\section{Research methodology}

The research on which the work was conducted is observational research that consisted of the study of biographies and documents published online by companies conducting market research or private companies interested in identifying critical factors with a direct impact on business efficiency (Stegaroiu et al, 2020). The research methodology used is the method of investigation, a method that belongs to the category of inductive methods, methods that allow the researcher to play an active role in increasing their knowledge and understanding of the world around them. We thus transpose the critical success factors of the analysed personalities (Table 2) in order to formulate a successful entrepreneurial model that can be applied at the level of companies.

Table 2. Principles of possible success in entrepreneurship

\begin{tabular}{|c|c|c|c|c|c|c|c|c|c|c|}
\hline Critical success factors & 1 & 2 & 3 & 4 & 5 & 6 & 7 & 8 & 9 & 10 \\
\hline Supreme Mind (egregore) & $\mathrm{x}$ & $\mathrm{x}$ & $\mathrm{x}$ & $\mathrm{x}$ & $\mathrm{x}$ & $\mathrm{x}$ & $\mathrm{x}$ & $\mathrm{x}$ & $\mathrm{x}$ & $\mathrm{x}$ \\
\hline The importance of a clear purpose & $\mathrm{x}$ & $\mathrm{x}$ & $\mathrm{x}$ & $\mathrm{x}$ & $\mathrm{x}$ & $\mathrm{x}$ & $\mathrm{x}$ & $\mathrm{x}$ & $\mathrm{x}$ & $\mathrm{x}$ \\
\hline Confidence & $\mathrm{x}$ & $\mathrm{x}$ & $\mathrm{x}$ & $\mathrm{x}$ & $\mathrm{x}$ & $\mathrm{x}$ & $\mathrm{x}$ & $\mathrm{x}$ & $\mathrm{x}$ & $\mathrm{x}$ \\
\hline The habit of saving & & & & & & & & & $\mathrm{x}$ & $\mathrm{x}$ \\
\hline Initiative and leadership & $\mathrm{x}$ & $\mathrm{x}$ & $\mathrm{x}$ & $\mathrm{x}$ & $\mathrm{x}$ & $\mathrm{x}$ & $\mathrm{x}$ & $\mathrm{x}$ & $\mathrm{x}$ & $\mathrm{x}$ \\
\hline Imagination & $\mathrm{x}$ & $\mathrm{x}$ & $\mathrm{x}$ & $\mathrm{x}$ & $\mathrm{x}$ & $\mathrm{x}$ & $\mathrm{x}$ & $\mathrm{x}$ & $\mathrm{x}$ & $\mathrm{x}$ \\
\hline Enthusiasm & $\mathrm{x}$ & $\mathrm{x}$ & $\mathrm{x}$ & $\mathrm{x}$ & $\mathrm{x}$ & $\mathrm{x}$ & $\mathrm{x}$ & $\mathrm{x}$ & $\mathrm{x}$ & $\mathrm{x}$ \\
\hline Self-control & & & & & & $\mathrm{x}$ & $\mathrm{x}$ & $\mathrm{x}$ & $\mathrm{x}$ & $\mathrm{x}$ \\
\hline Do more than you are paid to do & $\mathrm{x}$ & $\mathrm{x}$ & $\mathrm{x}$ & $\mathrm{x}$ & $\mathrm{x}$ & $\mathrm{x}$ & $\mathrm{x}$ & $\mathrm{x}$ & $\mathrm{x}$ & $\mathrm{x}$ \\
\hline A pleasant personality & & & & & $\mathrm{x}$ & $\mathrm{x}$ & $\mathrm{x}$ & $x$ & $\mathrm{x}$ & $\mathrm{x}$ \\
\hline Precise thinking & $\mathrm{x}$ & $\mathrm{x}$ & $\mathrm{x}$ & $\mathrm{x}$ & $\mathrm{x}$ & $\mathrm{x}$ & $\mathrm{x}$ & $\mathrm{x}$ & $\mathrm{x}$ & $\mathrm{x}$ \\
\hline Concentration & $\mathrm{x}$ & $\mathrm{x}$ & $\mathrm{x}$ & $\mathrm{x}$ & $\mathrm{x}$ & $\mathrm{x}$ & $\mathrm{x}$ & $\mathrm{x}$ & $\mathrm{x}$ & $\mathrm{x}$ \\
\hline Cooperation & $\mathrm{x}$ & $\mathrm{x}$ & $\mathrm{x}$ & $\mathrm{x}$ & $\mathrm{x}$ & $\mathrm{x}$ & $\mathrm{x}$ & $\mathrm{x}$ & $\mathrm{x}$ & $\mathrm{x}$ \\
\hline Take advantage of a failure & $\mathrm{x}$ & $\mathrm{x}$ & $\mathrm{x}$ & $\mathrm{x}$ & $\mathrm{x}$ & $\mathrm{x}$ & $\mathrm{x}$ & $\mathrm{x}$ & $\mathrm{x}$ & $\mathrm{x}$ \\
\hline Tolerance & & & $\mathrm{x}$ & & $\mathrm{x}$ & $\mathrm{x}$ & $\mathrm{x}$ & $\mathrm{x}$ & $\mathrm{x}$ & $\mathrm{x}$ \\
\hline The Golden Rule & $\mathrm{x}$ & $\mathrm{x}$ & $\mathrm{x}$ & $\mathrm{x}$ & $\mathrm{x}$ & $\mathrm{x}$ & $\mathrm{x}$ & $\mathrm{x}$ & $\mathrm{x}$ & $\mathrm{x}$ \\
\hline
\end{tabular}

Source: Author's interpretation (1. N. Bonaparte; 2. T. Lenk; 3. W. Churchill; 4. A. Hitler; 5.

Queen Elisabeth I; 6. Catherine the Great; 7. G. Potemkin; 8.E. Teodoroiu; 9.M. Gandhi; 10.D. Lama)

\section{Results}

Analysing the information shared above, studied in this research by developers, we see that the great leaders:

- they have a clear vision of a future, mentally projected reality; 
- have one or more types of intelligence (logical-mathematical, spatial, linguistic, intrapersonal, interpersonal);

- have an adequate education and have sufficient or in-depth knowledge that gives them a much more complete perspective on reality, probabilities and possibilities than in the case of most people and, implicitly, creates access to a generous reservoir of resources and solutions;

- they show courage, perseverance, creativity

- appreciates the effort and recommends the results

- the desire for power is manifested by seven of the ten leaders who have been the subject of research, but it is not manifested in people with a high level of understanding, such as M. Gandhi or D. Lama;

- the doubtful character manifested by cowardice, lack of empathy, mischievous and superior attitude and even cruelty is what disconnects the leader of people and leads to his decline in the organization;

- excessive control, such as that shown by A. Hitler, the leader who trusted only in his own person and who had disconnected from reality through his dictatorial behaviour, generates only operational and managerial inefficiency.

From this perspective, our results are summarized in Table 3.

Table 3. Qualities for entrepreneurship

\begin{tabular}{|c|c|c|c|c|c|c|c|c|c|c|}
\hline Positive attributes & 1 & 2 & 3 & 4 & 5 & 6 & 7 & 8 & 9 & 10 \\
\hline Vision & $\mathrm{x}$ & $\mathrm{x}$ & $\mathrm{x}$ & $\mathrm{x}$ & $\mathrm{x}$ & $\mathrm{x}$ & $\mathrm{x}$ & $\mathrm{x}$ & $\mathrm{x}$ & $\mathrm{x}$ \\
\hline $\begin{array}{l}\text { Logical-mathematical intelligence } \\
\text { (ability to elaborate reasoning, to } \\
\text { recognize and use abstract schemes } \\
\text { and relationships, structures, } \\
\text { formulas, technology, mathematical } \\
\text { concepts) }\end{array}$ & $\mathrm{x}$ & $\mathrm{x}$ & $\mathrm{x}$ & $\mathrm{x}$ & $\mathrm{x}$ & $\mathrm{x}$ & $\mathrm{x}$ & & & $\mathrm{x}$ \\
\hline $\begin{array}{l}\text { Spatial intelligence (sense of } \\
\text { orientation in space and very good } \\
\text { visual memory) }\end{array}$ & $\mathrm{x}$ & $\mathrm{x}$ & & $\mathrm{x}$ & & & $\mathrm{x}$ & & & \\
\hline $\begin{array}{l}\text { Linguistic intelligence (ease in } \\
\text { expressing and perceiving the } \\
\text { nuances of verbal language, the } \\
\text { ability to learn foreign languages and } \\
\text { use language to achieve goals but } \\
\text { also the ability to use language } \\
\text { effectively to express yourself } \\
\text { theoretically and poetically) }\end{array}$ & & $\mathrm{x}$ & $\mathrm{x}$ & $\mathrm{x}$ & $\mathrm{x}$ & $\mathrm{x}$ & & & $\mathrm{x}$ & $\mathrm{x}$ \\
\hline $\begin{array}{l}\text { Intrapersonal intelligence } \\
\text { (understanding one's own person; } \\
\text { introspective people, who have the }\end{array}$ & & & & & $\mathrm{x}$ & $\mathrm{x}$ & & & $\mathrm{x}$ & $\mathrm{x}$ \\
\hline
\end{tabular}


ability to analyze their own

emotions, thoughts, fears,

motivations and use them to guide

behavior)

Interpersonal intelligence

(understanding others; people who

prefer to socialize and empathize

with groups of people, are talented

in communication and negotiation,

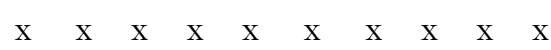
are concerned with understanding the intentions, motivations and desires of others)

Inner power/Courage

Perseverance

$\begin{array}{lllllllllll}x & \mathrm{X} & \mathrm{X} & \mathrm{x} & \mathrm{X} & \mathrm{X} & \mathrm{x} & \mathrm{X} & \mathrm{x} & \mathrm{X}\end{array}$

Education

$\begin{array}{lllllllllll} & x & x & x & x & x & x & x & x & x & x\end{array}$

Creativity

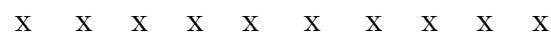

Compassion

$\mathrm{x}$

$\mathrm{x}$

Appreciation and reward

X $\mathrm{X}$

$\mathrm{x} \quad \mathrm{X}$

$\begin{array}{lll}\mathrm{X} & \mathrm{X}\end{array}$

Sacrificial power

X X

Wisdom

$$
\begin{array}{ccc}
X & X & X \\
& x & x
\end{array}
$$

Source: Author's results (1. N. Bonaparte; 2. T. Lenk; 3. W. Churchill; 4. A. Hitler; 5. Queen Elisabeth I; 6. Catherine the Great; 7. G. Potemkin; 8.E. Teodoroiu; 9.M. Gandhi; 10.D. Lama)

\section{Conclusions}

An entrepreneurial initiative can be a real success by summing up the external and internal determinants. The same entrepreneurial initiative can be a total failure if even one of these factors changes. Implementing ideas is not an easy process, but the profile of entrepreneurs is crucial to define a business idea and implement it successfully. It is important to mention that there is also the possibility of developing entrepreneurial characteristics through education (Sousa \& Almeida, 2014).

Therefore, identifying the key factors in entrepreneurship is a strong starting point for any entrepreneur who wants to be successful because awareness of basic virtues, proactive thinking patterns and ethical behaviours is the foundation of sustainable action. But only by applying this knowledge in an organized way did the information turn into effective power. Immersed in persevering action and oriented towards a clear main goal, it becomes the driving force generating entrepreneurial success.

The results presented are consistent with the results of other study conducted by Google, for over three years, by monitoring over 180 teams with over 
50,000 employees in the "Aristotle" project, the performance of a team depends on:

- Psychological safety: the feeling of security regarding the consequences of interpersonal risks of team members

- Keeping promises: people do what they say, they are available when they are needed and when they are promised they are available

- Structure and clarity: people need clarity on: -individual and collective expectations, -work processes through which they can meet these expectations, personal implications if the team achieves the expected results

- Meaning and significance: the writer Andrew Solomon states that the discovery of meaning responds to the need to have a WHY (why so, why me, why I...) to justify the life story.

The impact of this research: high-performing people want to know the impact that the collective effort of teammates has in the organization and outside the organization. The performances are obtained by those who, from the very beginning, aimed to contribute significantly to the achievement of the relevant results of the organization.

\section{References}

Avram, A. (2014). Famous women of Romania (vol. 2). Alpha Publishing House.

Beattie, S. (2016). Which entrepreneurial traits are the most critical in determining success?

Otago Management Graduate Review, 14(1), 13-20.

https://www.otago.ac.nz/management/otago643843.pdf

Blin, A. (2013). Timur Lenk. Corint Publishing House.

Buckley, J. (2019). Adolf Hitler. Niculescu Publishing House.

Eding, J. (2016). Who was Queen Elizabeth? Pandora-M Publishing House.

Fremont-Barnes, G. (2014). Napoleon Bonaparte. Litera Publishing House.

Gandhi, A. (2019). The gift of anger and other lessons from my grandfather. Humanitas Publishing House.

Hill, N. (2014). The magic ladder to success. Litera Publishing House.

Johnson, B. (2016). Churchill factor. How one man changed history. Litera Publishing House.

Lama, D. (2018). The book of wisdom. Curtea Veche Publishing House.

Lama, D. (2019). Freedom in exile. Herald Publishing House.

Makhbul, Z. M., \& Hasun, F. M. (2011). Entrepreneurial success: An exploratory study among entrepreneurs. International journal of business and management, 6(1), 116. https://doi.org/10.5539/IJBM.V6N1P116

Markman, G. D., \& Baron, R. A. (2003). Person-entrepreneurship fit: why some people are more successful as entrepreneurs than others. Human resource management revien, 13(2), 281-301. https://doi.org/10.1016/S1053-4822(03)00018-4

Montefiore, S.S. (2016a). Catherine the Great \& Potemkin an Imperial Love Story. Trei Publishing House.

Montefiore, S.S. (2016b). Titans of History The giants who shaped our world. Litera Publishing House. 
Orbach, D. (2020). Conspiracies against Hitler. Rao Publishing House.

Rolland, R. (2019). Mahatma Gandhi. A legendary life. Herald Publishing House.

Santos, F. M. (2012). A positive theory of social entrepreneurship. Journal of business ethics, 111(3), 335-351. https://doi.org/10.1007/s10551-012-1413-4

Shelden, M. (2014). Winston Churchill. Young Titan, Rao Publishing House.

Simu, O. (2008). The Green Stud - Notes from the healer Sofur about Timur Lenk. Herald Publishing House.

Sousa, M. J., \& Almeida, M. D. R. (2014). Entrepreneurial skills development. Recent Advances in Applied Economics, 135-139. http://www.wseas.us/elibrary/conferences/2014/Lisbon/AEBD/AEBD-18.pdf

Stegaroiu, I., Radu, V., Simsek, H., \& Tabirca, A. I. (2020). Impact of Leadership Team Values and Performance on Organizational Behavior. LUMEN Proceedings, 10, 241 251.

https://proceedings.lumenpublishing.com/ojs/index.php/lumenproceedings/artic le/view/221 